\title{
The Charming Soul of a Street in Rio de Janeiro
}

\section{Paulo Afonso Rheingantz and Denise de Alcantara}

Paulo Afonso Rheingantz, $\mathrm{PhD}$, is an associate professor, and Denise de Alcantara, $\mathrm{PhD}$. is a part time lecturer at the School of Architecture and Urbanism, Federal University of Rio de Janeiro. From May 2008 to January 2009, Paulo was a visiting scholar at $\mathrm{Cal}$

Poly's CRP Department. Denise is the CILAS 2008-09 Visiting Scholar, University of California San Diego.
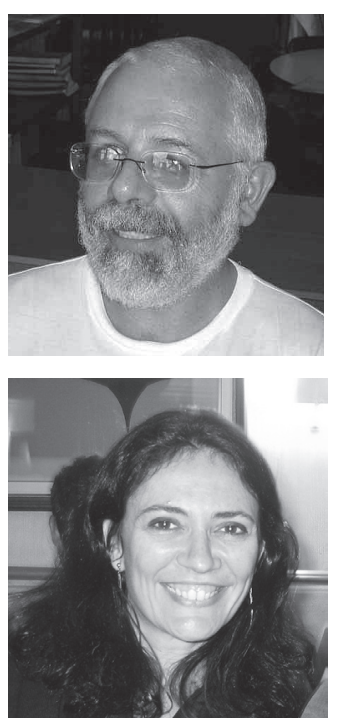

1 Authors' translation from the original in Portuguese: "A rua era para eles (dicionários e enciclopédias) apenas um alinhado de fachadas por onde se anda nas povoações ... Ora, a rua é mais do que isso, a rua é um fator de vida das cidades, a rua tem alma! .. a rua é agasalhadora da miséria. ...é generosa. $\mathrm{O}$ crime, o delírio, a miséria não os denuncia ela. .. a rua denuncia para 0 animal civilizado todo o conforto humano".
Based on their research project on the quality of places, Paulo Rheingantz and Denise de Alcantara, discuss the attributes and qualities of a residential street in Rio de Janeiro which is very cherished by the community. Their approach uses a mix of methods -including experiential and morphological- which help to understand the built environment from different perspectives and capture the "soul" of the street.

\begin{abstract}
"For them (dictionaries and encyclopedias) the street was just aligned façades where one walks through in villages... Oh, the street is much more than that; the street is the meaning of city life; the street has soul! ... The street shelters misery. ... It is generous. It does not reveal the crime, the daydream, the misery. ... The street reveals for the civilized animal all the human comfort." ${ }^{1}$ (João do Rio, 1995: 4)
\end{abstract}

In this article we discuss a study on the quality of place, and specifically the quality of the street, a fundamental component in defining a place. Our case-study is Rua Pires de Almeida, one of Rio de Janeiro's streets that best represent the sentiment expressed in João do Rio's manifest The Enchanted Soul of Streets (Rio, 1995).

This article presents part of a research carried out in Rio de Janeiro during 2006-2007, which was developed in two stages, and was the first attempt to apply the experiential approach in an urban setting. The experiential approach was developed by our research group based on the works of Maturana (2001) and Varela et al (2003). We published on the development of this approach elsewhere (Rheingantz \& Alcantara, 2007). The experiential approach characterizes the human experience in the place, since it considers how each place at each moment influences human actions, and how human presence provides sense and meaning to each place. Human sensorial and motor abilities constitute a fundamental part in the cognitive process and include verbal and non-verbal language. On one hand in a broader biological, psychological and cultural context, these abilities do not exist if there is no interaction with the environment that is experienced. On the other hand, the environment cannot exist without the human existence to experience it; both are inseparable aspects of the experiential approach.

The first phase of our research, concentrated on applying the experiential approach itself and in analyzing how residents, users and visitors interacted with the space: using, appropriating, and feeling the space as a place. Interviews, informal conversations and embodied observations were carried out according to this approach and focused on the subjective (socio-cultural) aspects of the place (Alcantara, 2006).

The emphasis in the present article is on the second phase of the research, which focused on the object, or on the physical and morphological aspects of this unique urban setting, Rua Pires de Almeida as a place. Our urban design references were based on Lynch (1960), Tuan (1974), Alexander et al (1977) and Ashihara (1983). These attributes were evaluated and re-signified according to the attitude of the observer and his/her experiential perspective. In the analysis of streets, sidewalks and public spaces,

Note: This article is a revised and shortened version of Rheingantz, P.; Alcantara, D.; Barbosa, A., 2008. "Pires de Almeida: Reduto da Alma Encantadora das Ruas do Rio de Janeiro". In Comas, C. (ed.) O Moderno já Passado, o Passado no Moderno - Reciclagem, Requalificação, Rearquitetura. UniRitter Porto Alegre: FAU-UniRitter, 2009. Translation by the authors, revised by Vicente del Rio. 
we're also inspired by the anti-modernist insights of Jacobs (1961), her poetic analogy of the windows as 'the eyes of the streets', and the recognition of the richness of meanings, safety and quality of life provided by the combined diversity of uses and non- ordered density of the traditional city.

Based on the experiential approach and on the understanding that knowledge is a net of "sociotechnical interfaces" (Latour, 1999), each object or event is conceived as a mix or a "collective" composed of men, things, and techniques, where border lines between the subject and the object are erased. For us, the term "collective" reflects an adequate notion that refers to the association and mediation processes between humans, nature and technology, much like a built environment being used. The notion of collective reinforces this study's premise that our world is built with the others based on our experience in the environment and our topophilia - love of place. ${ }^{2}$

When we experience a "good" environment, this evaluation is based on our own perspective as observers; an evaluation that does not simply rely on objective aspects but is dependent of our own experience. According to Antônio Lobo Antunes ${ }^{3}$, an urban environment only works when it becomes a "living organism" that changes and moves out of the control of its designer. In the same sense, to gather the knowledge resulted from a place - where the place's own life and emotions escape from the control of the observer - is only possible with the intertwining of technology, nature and society (in this case, the users), the architectural and urban elements, and the subjective aspects emerging from their interactions.

The understanding of place as a "cultural enclosure" 4 transcends its physical-social aspects and suggests that the reality that one experiences is different from that which results from the concepts used to interpret the place. These concepts "may be too rigid or too limited to express the dynamic nature of the mind and body senses" (Tulku, 1995: 229). Notions of agreeability, imageability, place belonging, human behavior to environmental conditions and body signs, are influenced by cultural heritage (Rheingantz et al 2002).

The materiality and characteristics of the morphological attributes of Rua Pires de Almeida were analyzed and we could verify how their results matched those found by Alcantara et al (2006). Our objective was to investigate the nature of Latour's notion of the "collective" dimension and the contribution of this dimension to the character of the place.

\section{Pires de Almeida: The place}

Local and neighborhood newspaper articles agree on the positive image of Rua Pires de Almeida as a place, and its high value in all levels: material, immaterial, sentimental and subjective. This sentiment is expressed in the words of one of its young residents:

"The tranquility and safety of this neighborhood allow children and youngsters to play and talk until late at night in the square, elected the place's best spot. All my friends are here. Everyone knows each other and I feel safe to stay until one, two in the morning in the square. It is very calm here". 5

The assertion "I love the street" (Rio, 1995) states the residents' feelings that, generation after generation, inhabit this small residential area. Its historical importance is not only related to the quality of its architectural design. Through the years this neighborhood had several artists and personalities and served as a refuge to critics of the military regime during the dictatorship in Brazil.

While Pires de Almeida is the name of a street, for years it has been used in reference to the complex of residential buildings that define it and its small park. It is located off Rua das Laranjeiras, a major
2 Topophilia is the affective connection between a person and a place or physical environment, concept originally developed by environmental geographer Yi-Fu Tuan (1974).

${ }^{3}$ Famous Portuguese writer and winner of The Camões Award 2007. In O Globo, March 16, 2007, 2nd Section, p.2.

${ }^{4}$ Culture is a set of representative, directive and affective systems of meanings shared by social-cultural groups (Rheingantz, del Rio \& Duarte, 2002). The constituents of these groups recognize themselves as members of an interactive community and communicate and articulate between themselves through behaviors, expectations and beliefs. In adapting to an urban setting, a human group shapes its environment and consequently provokes changes to the relational logics of the group in a circular, dynamic and recurrent process.

5 "Vila Pires de Almeida: Marselha é aqui". In Folha da Laranjeira, July 2001, p. 8 
${ }^{6}$ After its total closure in 1938, the remnants of Fabrica Aliança were replaced by a much larger residential development. Located only two blocks away from Pires de Almeida, in a small valley, the Jardim Laranjeiras (Laranjeiras Garden) has twelve 12-story residential buildings with retail on the ground floor along a beautifully landscaped street, and single family and walk-ups apartments up surrounding hills. See del Rio et al, 2001.

${ }^{7}$ In 1985 the city passed a law listing the first four buildings as historic monuments, and in 1991 the whole project site was declared a cultural preservation zone. artery running down a tight valley, between the districts of Laranjeiras and Cosme Velho. These district's $19^{\text {th }}$ century aristocratic mansions and ranchettes have been long replaced by intense urbanization, high density, and tall buildings. They are mostly residential districts with most of their commercial and office uses concentrated along Rua das Laranejrias. In 1965, the opening of Rio's longest tunnel higher in the valley with ramps connecting to Rua das Laranjeiras transformed it into one of the busiest traffic corridors in the city.

By the late $19^{\text {th }}$ century, the textile factory Fabrica Aliança and its mills occupied a large area including what now is Rua Pires de Almeida. In 1927, an area of 150,000 square-feet containing a mill and the workers' housing were sold out to an insurance company who replaced it with a residential complex rented out to the company's employees and to executives of the old factory. ${ }^{6}$ Named Jardim Sul America (South American Garden), the project included 23 buildings with 158 residential units of 1 to 4 bedrooms, and a small park. All buildings were built to the front and side lot lines, their layouts corresponded to the hierarchy of the employees in the company (the higher up the better the apartment), and the best apartments had allocated garages built in the back of the buildings. By 1956, all units were sold out and many of them still belong to their first owners or descendents.

The project is defined by three distinct sectors, ordered according to the types of apartments and the residents' hierarchy in the company (Figs. 1 and 2). Sector A holds four 6 storey-buildings with 1,800 square feet four-bedroom apartments. Two of these buildings are placed at the entrance of the development at Rua das Laranjeiras (Fig. 3). As these buildings were meant to higher-level employees, their lobbies, staircases and hallways were finished with imported marble, two segregated elevators and stairways served "social" and "service" uses, they had small street setbacks and balconies with decorated iron rails. ${ }^{7}$

Sector B holds six four-story walk-ups with 1,000 sqf three-bedroom apartments surrounding and demarcating the small park Praça Múcio Leitão. Their parking spaces were located behind the buildings and were later incorporated to the deeds of the apartments when the units were sold out (Fig. 4). Sector $C$ lays along the street that at this point is narrower and follows a gentle slope up and a subtle bend to the right (Fig. 5). The sector holds thirteen four-story walk-ups with one, two and

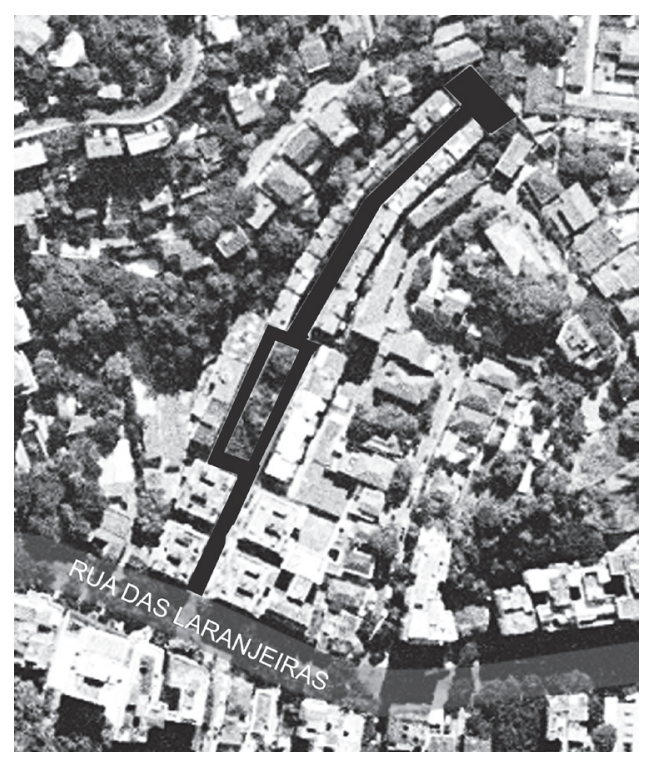

Figure 1

Rua Pires de Almeida in the neighborhood context. (Digitalized satellite photography - IPP Collection)
Figure 2

The study sectors in Pires de Almeida Street. (Digitalization over cadastral map )

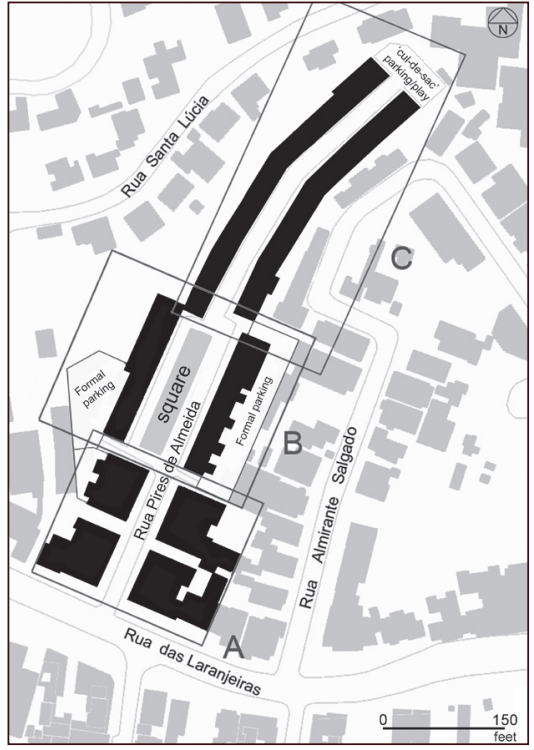


three-bedroom apartments built right at the sidewalk form continuous rows on each of the narrow street, accentuating its curvilinear design almost into a "crescent". Here the architecture is simpler but keeps the overall project identity. At the top, the street ends at a cul-de-sac with three of its sides defined by high containing walls made of heavy stone (Fig. 6). The cul-de-sac doubles as a parking lot and an informal recreation space for residents, and it provides a beautiful view back over the street and the buildings towards Corcovado Mountain and the Statue of Christ the Redeemer, one of Rio's most famous landmarks.

The buildings and the apartments' floor plans reflect the strong social hierarchy of the development, and all had small studios in the attic for maids and servants. In the art deco façades, doors and windows are framed with geometric designs and balconies overhang over the small street setback,

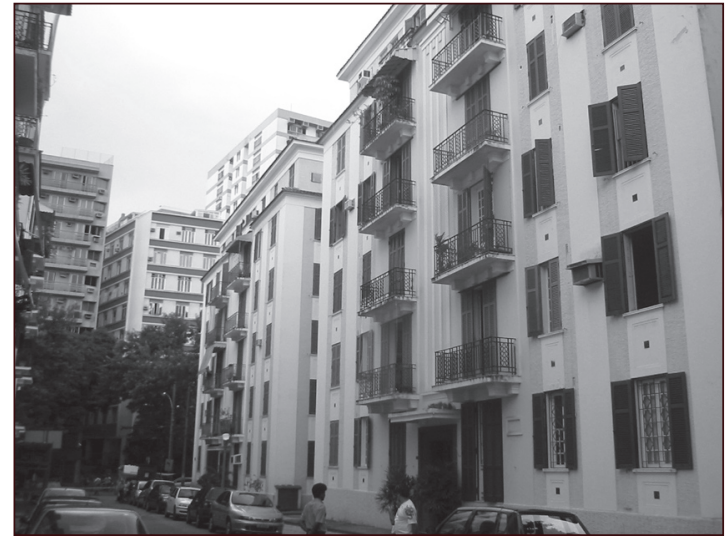

Figure 3

Study Sector A looking out to Rua das Laranjeiras; these are the buildings originally built for the highest income families.

Because of Rua Pires de Almeida's historical and architectural values, it has been used as a set for movies and TV shows; the street and the square are usually used as the background. Recently, one of these productions paid for the renovation of the public spaces and building façades as a counterpart for the community.

\section{Urban Quality}

We started our study by analyzing the physical and spatial attributes of Rua Pires de Almeida's as an urban setting, in order to complement the information revealed by the survey. Next, we will discuss the general findings of the visual analysis that was performed, and the details and aspects that add meaning to the building façades.

As a theoretical backdrop for the qualities of a place, we used Alexander et al's (1977) pattern language, particularly the patterns "identifiable neighborhood", "small public plazas", "buildings" and "complexes of buildings". We also associated architectonic types to the distinctions between prose and poetry proposed by Alexander et al (1977: xii): "The differences between prose and poetry is not that different languages are used, but that the same language is used differently". The visual language allows the conception of prosaic or poetic environments ${ }^{8}$.

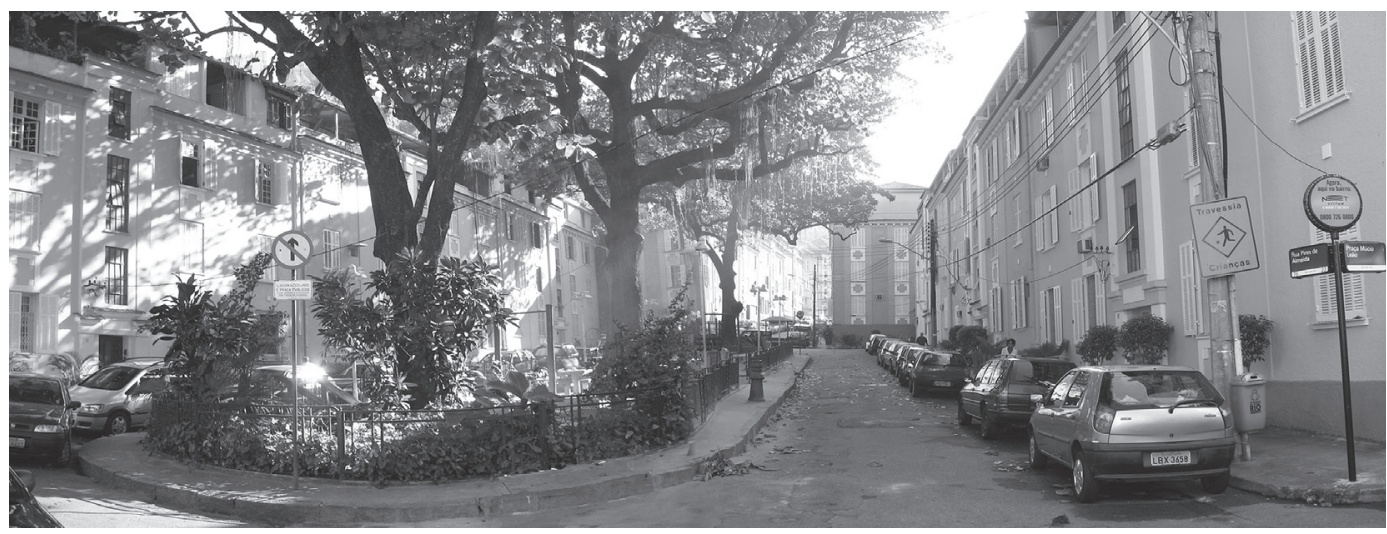

8 This approach reflects the experiential perspective and that "we are language-able beings" (Maturana 2001).

\section{Figure 4}

Sector $B$ consists of the small square Praça Múcio Leitão and the buildings around it. (Photo by Alexandre Barbosa) 


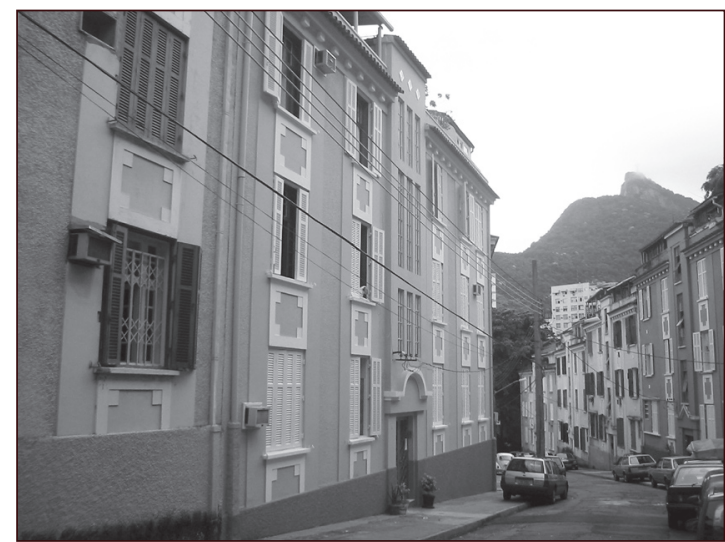

Figure 5

In Sector $C$ the street curves and slopes up. The trees in the small square and the Corcovado Mountain can also be seen in the background.

\section{Figure 6 \\ The cul-de-sac at the top is used by the residents for informal parking, recreation, and public events.}

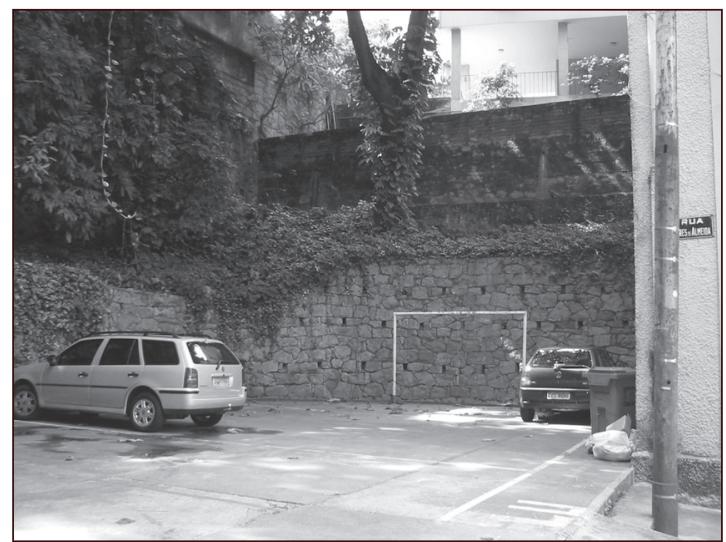

We also applied concepts for the composition of external spaces by Ashihara (1983), particularly regarding scale, texture, positive/negative space and hierarchy, and the relationship between the dimensions of a local square and the visual acuity. Jane Jacob's anti-modernist manifest Death and Life of Great American Cities helped us to analyze the street, its sidewalks and public spaces. Jacob's poetic analogy of windows as the eyes of the street alerted us on the richness of meanings, security and quality of life provided by the combined diversity of uses and non-rigid densification of the traditional city. Finally, from the Greater London Council (1978), we applied the concepts of external and surrounding areas, integrative factors, organization and spatial enclosure types, scale and proportion, contrasts, building identity, details and territoriality.

\section{Identifiable Neighborhood}

According to Alexander et al (1981), in an identifiable neighborhood small human groups create synergy and character that give vitality to settlements. When residents identify with their neighborhood and perceive it as distinct to others they enjoy a sense of territoriality and appropriation, which can be clearly observed in Rua Pires de Almeida. The setting, despite its strong identity, integrates well with the surrounding district, and the main element of this integration is the small square, heavily used both by residents and the community living around the project.

A neighborhood with 500 residents should not have more than three blocks and its area should fit within a 900 feet circle. This attribute guarantees a sense of personal pride to the residents and adds value to their individuality through the territory's personalization. Also, considering that streets with intense and heavy vehicular circulation destroy the sense of community, it is important to prioritize walkability (Appleyard apud Alexander et al, 1981: 97). Both of these attributes are also present in Pires de Almeida Street.

Different scales of spatial appropriation are easy perceived, and distinctions between public (street and square), semi-public (garages and backyards) and private (units) spaces are clear. The cul-desac may be considered as a semi-public space since it is used and controlled by the residents. In the street and square, the feeling of being watched all the time is reinforced by the many windows of the surrounding apartments - including those on the ground level, where privacy is guaranteed by the level difference between the interior of the apartments and the sidewalk. There is a strong sense of belonging to the place even in the small details, as in the decorative plant pots that the residents placed on the sidewalks: they create buffers for pedestrian circulation between the buildings and the curb while discouraging irregular parking. 


\section{Small Public Squares}

Small public squares (pattern \# 61; Alexander et al, 1981) are usually generated by the widening of the main pedestrian routes that constitute activity and movement nodes. While large modern plazas are usually devoid of any human scale and use, when well-dimensioned small public squares encourage vitality, intense use and easy appropriation by the community. An average of $300 \mathrm{sq}$. feet per person is a good design parameter for a small square, and tends to generate attractive and comfortable environments, in an atmosphere that favors use and permanence.

Ashihara (1982) and Alexander et al (1981) recommends a limit of about 60 feet for visual identification of a person's face and voice, what relates to the sensation of safety. Ashirara (1982) also notes that the maximum distance for visual acuity with enclosure, safety and intimacy sensation in a small exterior space is of 22 to 27 meters $\times 22$ to 27 meters: people easily recognize each other faces, and the space is compact and provides intimacy. The small public square at Pires de Almeida fits within the recommendations, being 42-54 feet wide and 63 long.

The perception of buildings heights also depends on the human angle of vision at the street level. Approximately $20^{\circ}$ of a person's $60^{\circ}$ visual cones correspond to the perception of the lower level (below the horizontal line of vision) and $40^{\circ}$ to the higher level (above the horizontal line of vision). In order to guarantee the integration of the setting with the landscape in the background and with the sky, Ashihara (1982) recommends that the building height should not exceed $2 / 3$ of the superior visual line (approximately $27^{\circ}$ ). Again, the public square at Pires de Almeida has these attributes (Fig. 7).

The square in our case study also contributes to the neighborhood's identifiable pattern and is a reference of use to residents and the surrounding community. As such, it can be considered both as a node and a landmark for its central position, besides the fact of being the daily route of most residents (Lynch, 1960). Users change in different times of the day: children and their playful activities, elderly people that talk, rest or contemplate the place; teenagers and youngsters that, late afternoons or at night, flirt and date in low light. The scale and shape of the square generate a nice atmosphere where the sensation of enclosure and sheltering is provided by the buildings framing it. The tall tree canopies are like a "green roof" and create a pleasant microclimate and a refreshing and protective feeling.

The built environment must be comfortable and protective to support exterior activities that are complementary to the residences (GLC, 1985). A place's spatial organization is fundamental for it to be integrated to the existing urban fabric, to have agreeable and sheltering spaces, and to ensure that the relationship between people and spaces will contribute to the sense of place.

If analyzed against the various types of enclosure defined by a group of buildings, the square at Pires de Almeida may be considered a less rigid variation of a community square or a large housing patio, representing a visually static resting place (Fig. 8). The square's configuration favors the social interaction between neighbors while providing a feeling of privacy. Having the through street on one of its sides also helps protecting the square from vehicular traffic while keeping it close enough to the action that happens along all the sidewalks. Pires de Almeida Street provides an environment that is calm and conductive to the feeling of visual and physical protection.

\section{Building Complex}

In their pattern \#95, Alexander et al (1981) note that a building complex

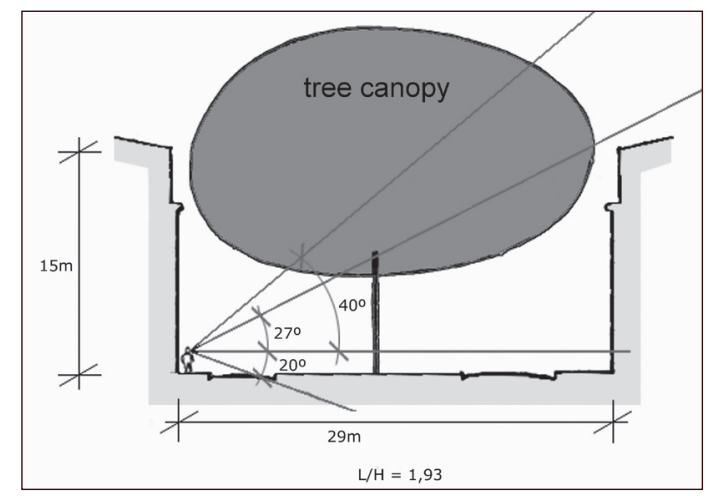

Figure 7

Cross section of the square showing the angles of vision according to Ashihara (1982). 


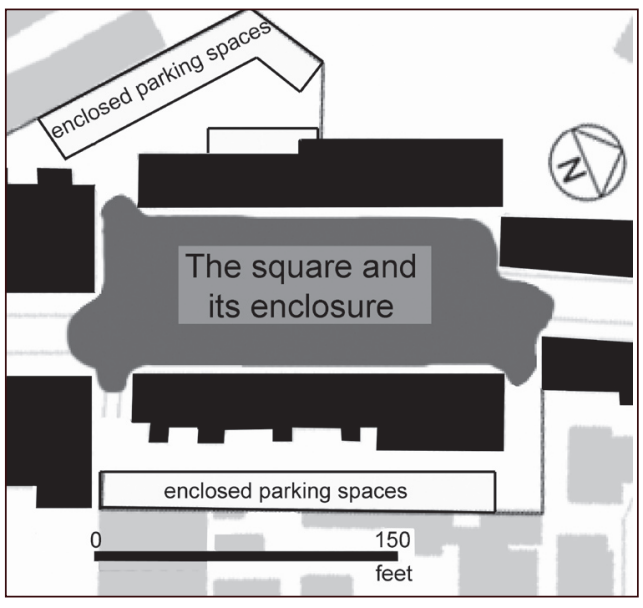

Figure 8

The feeling of enclosure is stressed by the square angles along the edges, according to the Greater London Council (1985). Note the spaces behind the buildings adapted for parking by the residents.

${ }^{9}$ According to Alexander et al (1980) when L/H < 1 there is an increase in the feeling of enclosure/ claustrophobia, and when $1<\mathrm{L} / \mathrm{H}>2.5$ there is a lack of enclosure. must contain identifiable parts, especially in multi-family housing, in order to humanize it and to express the social relationships of residents. Among the recommended design attributes for an ideal housing project are: low-density per building, 3 to 4 stories to keep the human scale, buildings should be narrow, aligned to the street line, and have independent accesses. All of these attributes are present in the building complex at Pires de Almeida Street.

These authors also observe that to better create positive pedestrian routes and social spaces building façades should be located at the front of the lot. Generally, setbacks fail to add value to the public space and damage the character of the street. The smooth angles, the absence of setbacks, and openings in the ground floor are aspects of the traditional city that provide well-being and comfort to users of the public space. Façades that are visually enriched with niches, small entrances, and a rhythmic composition of elements generate a visually interesting dynamic set. Those relations are present and reinforce the identity and meaning of the complex, favoring human contact among its users (Alexander et al 1981).

The literature also suggests that proper natural light and ventilation are guaranteed through the correct relation between building height and street width. In Pires de Almeida, despite the relationships being below the recommended number, one still feels a pleasing visual effect in the configuration of the street space. While Alexander et al (1981) indicate $2.5<\mathrm{L} / \mathrm{H}>1$ as the ideal formula, the $\mathrm{L} / \mathrm{H}$ relationship in Sector "A" is 0.65 (enclosure minimized by the distance between the buildings), in Sector " $C$ " it is 0.7 , and at the square (Sector "B") it is 1.93 in the short direction and 4.6 in the long direction -both minimized by the roof effect of the tree canopies (Figs. 9 and 10). ${ }^{9}$

Regarding the overall composition the architectural consistency and the aligned buildings make the complex very harmonic in scale and proportion, the enclosure reinforces the spatial and visual qualities of the setting, way finding is very easy, and pedestrian circulation is clearly defined (despite the vehicles that park on part of the sidewalks because of the lack of designated parking places). The lack of contrast in the public space corridor along Pires de Almeida Street results in a strong spatial homogeneity, which is by the scale, the color of the buildings, the upper floor setback, and the large tree canopies. On the other hand, these secondary architectural elements, such as the decoration, planters, and quantity and sizing of doors and windows, tend to reduce the perception of scale and humanize the space.

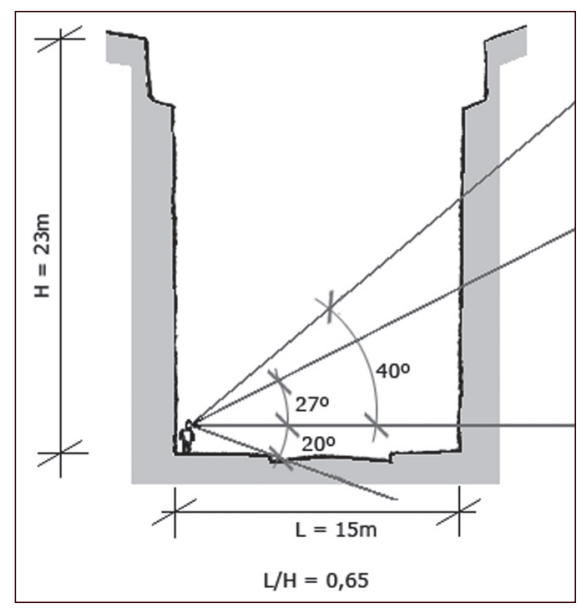

\section{Figure 9}

Ashihara's cone of vision in Sector A. (Drawing by Alexandre Barbosa)

Figure 10 Ashihara's cone of vision in Sector C. (Drawing by Alexandre Barbosa)

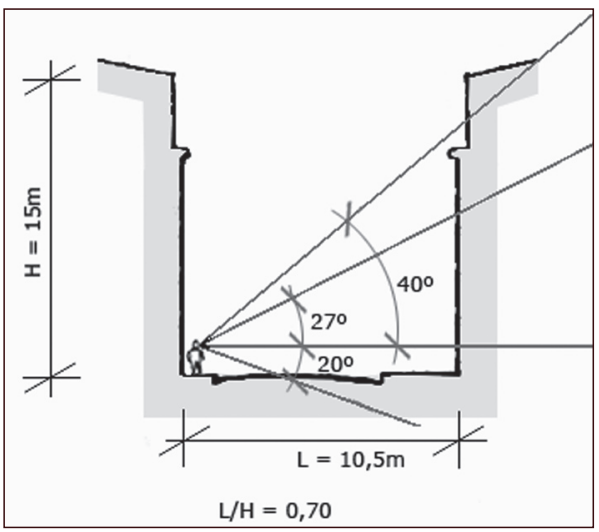


Spaces between buildings (spatial enclosure) stimulate human senses through the quality and characteristics of each place, from which emotions and human reactions emerge. At Pires de Almeida, the sheltering and protective enclosure of this unique place complement the privacy and feeling of security provided by the square's shape. It enhances the sense of place, discourages vandalism, and generates the residents' willingness to preserve the place, as opposed to what happens in most large cities. The overall urban design and the square's centrality also favor social contact among residents and other users from the surrounding community.

In places with distinct environments and spatial shapes, the continuity and contrast incite and induce users to naturally follow ahead. Walking by Pires de Almeida Street is always pleasant and the contrast is guaranteed by the changes in spatial types identified (sectors A, B and C); by the variation in size and scale of buildings and places; by variation in the enclosure levels and the elements that shape them (balconies, banks, entrance doors etc); and by the building heights, which in sector $\mathrm{C}$ is enhanced by the smooth slope (Fig. 11).

\section{Acesses and Entrances}

According to Alexander et al's pattern \#110, the main gateway to a place is what defines and controls the character of buildings and the in and out movements. When well- located it will define the entry way simply and naturally; and if poorly located, it will reflect negatively in the whole setting. The main entrance should be clearly visible, easily identified, and provide orientation to approaching users. Walking towards a clearly visible main entrance should be a natural and thoughtless decision, freeing one's attention to perceive other interesting elements along the route. The shape of an entrance should make it clear and easy to identify; elements such as color, frames and ornaments, and light and shadows, contribute to distinguish an entrance.

The area's single point of entry alone serves as a natural defensible space. This is intensified by the narrow street section that makes it impossible for more than one vehicle to enter/exit at the same time, reducing traffic, and facilitating the visual control of people driving or walking in and out of the complex.

A sequence of entryways in a side-by-side collection of buildings is defined as a Family of Entrances in Alexander et al's pattern \#102. In Pires de Almeida Street, the buildings' main entries are placed in their front facades, directly onto the sidewalks, contributing to street life and movement. These entryways are clearly identifiable and share similar design, although decoration and small variations ensure each building its own visual identity. Entryways are marked by vertical lines in stucco, geometric framings, and iron doors mostly painted in dark colors and contrasting with the pastel colors of the facades. In the four buildings of sector A, the overhang placed over the entryway, and the designs of the balconies reinforce the facades' vertical lines and strongly emphasize the point of entrance to the main lobby and the building.

\section{Figure 11}

A section along the street shows the gentle slope (80) upwards from Mucio Leitão Square. (Drawing by Alexandre Barbosa)

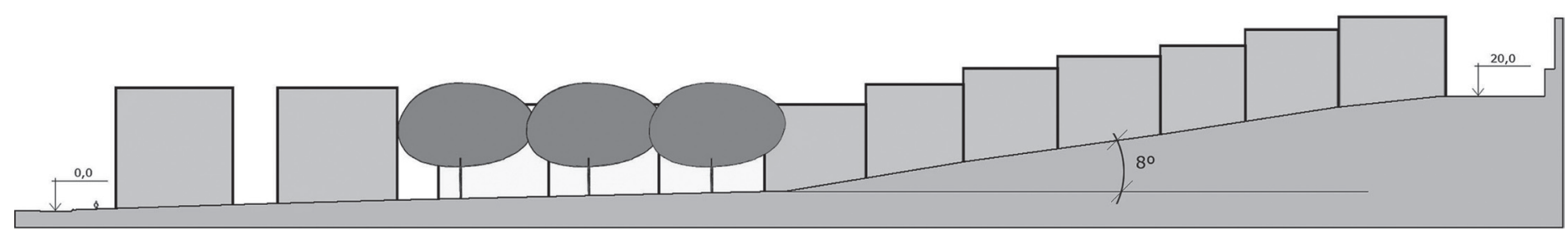


${ }^{10}$ The only exception is the building at the corner of the square.

${ }^{11}$ To this date, only one of the four buildings in sector A is protected by city regulations.
There is a symmetry and homogeneity of volumes, rhythms, openings, dimensions of windows, and decorative elements, despite the subtle variation in constructive details and ornaments. Sidewalks present stone mosaics that vary in textures and colors, are not ramped and have a level variation -one step up towards the buildings and away from the curb-contrary to today's accessibility criteria. There are no ramps to overcome these problems in any of the sidewalks except a ramp in the cul-desac at the top of the street to facilitate vehicular access to the temporary parking lot.

Finally, the strong unity of the setting is guaranteed by a coherent sequence of spaces, the controlled variation of the architecture, and a variety of connections between the spaces. The result is a dramatic visual effect that adds to the place's inviting and protective atmosphere.

\section{Not Everything is Perfect...}

Despite its charm, Pires de Almeida Street also has problems and negative aspects related to the design of the buildings, the overall maintenance, and to subjective aspects of the sense of collectivity. Some interventions and remodeling in the buildings has occurred with no criteria or planning. For example, the four buildings in sector A had collective laundry rooms located in the top story together with rooms for servants but in the 1950s and 1960s small laundry spaces were added to the apartment adjacent to the kitchen and servive area, altering the back facades of all buildings with only one exception ${ }^{10}$. One's attention is also drawn to the top of buildings in sectors $B$ and $C$ where the roof and the rooms for servants were originally recessed resulting on a terrace running along the whole front facade. The residents decided to increase their useable space by covering up the area that corresponded to their apartment, using different designs and materials. This resulted in significant changes in the buildings' original bulk and front façades that are visible from the street level.

Although less evident, other interventions in the façades show the lack of concern with the original design and identity of the original architecture, particularly in sector B where several of original window frames have been substituted for different models and materials. A grave problem in sector $A$ is the random installation of individual air conditioning units in the façades, whose location is not consistent with the exterior design. Nevertheless, because of the city's historic preservation regulations, most of the original architecture of the four first buildings - sector $A-$ are kept original and well maintained. ${ }^{11}$

The conflict between pedestrian circulation and car parking is a difficult solution; since it reflects a huge demand that is city wide. Since the number of parking spaces in Pires de Almeida is very restricted by today's standards and limited to the buildings of sector $B$, residents park their cars on the street, parallel to the curbs and even on sidewalks in sector A -the only ones in the complex that wide enough. Nearby commercial uses along Laranjeiras Street add to the problem since their employees and patrons also park there during the day. To discourage (but not prohibit) non-residents from parking in the complex, the residents installed a small booth at the corner of Pires de Almeida and Laranjeiras streets were a community-hired employee operates a lift bar.

Garbage disposal is another problematic issue, since the buildings have not been provided with enough spaces for containers and the pick-up truck comes only three times a week. In collection days, the garbage bins are placed in the corner of the square corner where they remain for a couple of hours causing bad smells and attracting bugs and insects. Kids and other users of the square have to stand it until the garbage truck shows up and the containers are removed.

There are problems related to the behavior of both residents and users from the surroundings. One is due to the large amount of people who own dogs and usually do not clean after them; the sidewalks and the small square are as mine fields. The dogs' loud yelps also disturb the peace, what at times 
can get very annoying at night. But not only noisy dogs disturb the peace but also domesticated birds: a resident finally donated his parrot after receiving several complaints from angry neighbors...

Noise caused by teenagers in the square at night is also common, leading to a picturesque story from the early 1970s: an old resident whose bedroom faced the square used to open his window every thirty minutes at night to, calmly and well-mannered, announce the hour in loud voices, thus getting the nickname "the cucco"... However, some of the annoying noises of the neighborhood also serve as indicators of the place's vitality and its use by residents and the surrounding community. Like the noise produced by children playing in the square's playground, these little inconveniences are inherent to urban residential collectivities.

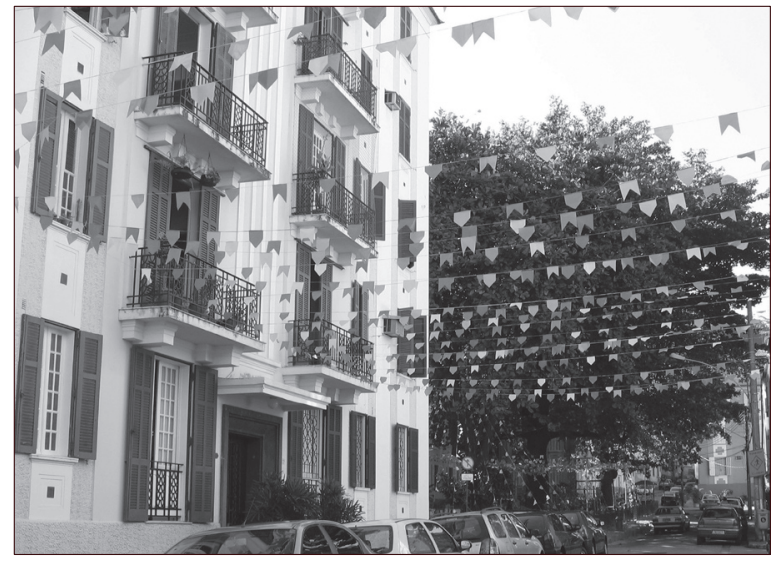

Figure 12

Pires de Almeida Street decorated for the traditional June street festivities.

And finally, not uncommon to large cities, appropriate maintenance of the public spaces in Pires de Almeida is a recurrent problem. The city does not keep up with landscaping, cleaning, and with the maintenance of sidewalks and street furniture including the square's playground.

\section{Final Remarks}

In our individual-oriented, privatized, globalized world and faceless cities, the enchanted soul of the street still prevails at Pires de Almeida. This soul is also expressed through the community appropriation of public spaces; street and square become a natural stage for social events. Neighbors know one another, socialize in the public space, and promote street events. For example, once or twice a month on Saturdays afternoons, a local resident organizes high-spirited rodas de choro ${ }^{12}$ that sometimes break into the night. Every June, residents decorate the street for the traditional Saint Peter-Saint Paul festivities, which in 2005, lasted for 3 days and 3 nights (Fig. 12). During soccer world cups, the community share dreams and commemorate every victory of the Brazilian team. Residents also unite against governmental decisions that affect the local or to demand such actions to solve daily issues and problems -as happened recently during a dengue fever outburst. ${ }^{13}$ These social manifestations reinforce the spirit of the collective and the topophylia in this small robust container of the city memories.

The first stage of our research, its experiential approach and the embodied observations, we analyzed the social, cognitive, and physical aspects of Pires de Almeida, this helped us identify a very positive assessment of the complex as a place (Alcantara et al 2006). In the final stage, we could verify the subjective and objective attributes that intertwine and result in the quality of the place perceived by both residents and users. Our methodology permitted us to investigate the "world" Pires de Almeida as a collective reality that results from the urban design, the architecture, and the actions of residents, users, and admirers, who contribute in the creation of a harmonic and well-balanced environment.

The small inconveniences, the interactions, and environmental stimuli engender a significant and original place of resistance that results in a strong city culture that is deeply engraved in the life of its inhabitants, in contrast to the privatized condominiums and gated communities that now dominate cities and suburbs. The lessons learned from Pires de Almeida are clearly evidenced in its architectural and

\author{
12 Choro or chorinho \\ is a traditional urban \\ instrumental music genre \\ typical of Rio which first \\ appeared in the 1870s. \\ Based on virtuosity and \\ improvisation, players sit \\ around a circle and keep \\ challenging each other.
${ }^{13}$ The dengue fever is an infectious disease caused by a virus transmitted by the aedes aegypti mosquito who feeds from stagnant waters.


14 From the original in Portuguese: "Oh! Sim, as ruas têm alma! Há ruas honestas, ruas ambíguas, ruas sinistras, as nobres, delicadas, trágicas, depravadas, puras, infames, ruas sem história, ruas tão velhas que bastam para contar a evolução de uma cidade inteira, ruas guerreiras, revoltosas, medrosas, spleenéticas, snobs, ruas aristocráticas, ruas amorosas, ruas covardes, que ficam sem pinga de sangue ....". Free translation by the authors. urban elements as well as in the subjective aspects of community life, and they clearly point towards the excellence of the place's original design. These qualities must be rescued, preserved, and serve us in the teaching of urban design and planning so that they can inspire good city form.

"Oh! Yes. Streets have soul! There are honest streets, ambiguous streets, scaring, noble, delicate, tragic, depraved, pure streets, streets with no history, streets so old that they are enough to tell the evolution of the whole city, warrior streets, revolted, frightened, splenetic (sic), snob, aristocratic, loving, coward streets, that end up with no blood at all ..." ${ }^{14}$. João do Rio (1995: 7)

\section{References}

Alcantara, Denise; Rheingantz, P.; Barbosa, A.; Laureano, A.; Amorim, F. 2006. "Rua Pires de Almeida: Observação Incorporada de Um Lugar Público Particular”. In Paisagem e ambiente. São Paulo: USP, n. 22, p. 30-40.

Alexander, Christopher; Ishikawa, S.; Silverstein, M. 1977. A Pattern Language. New York: Oxford University Press.

Ashihara, Yoshinobu. 1983. The Aesthetic Townscape. Cambridge, MA: The MIT Press.

Cullen, Gordon. 1996. The Concise Townscape. Lisboa: Ed. 70.

del Rio, Vicente et al. 2001. "The Permanence of Urban Form in the Construction of a Place: Quality of Design in a 1930's Residential Area in Rio de Janeiro, Brasil”. In Proceedings of the International Seminar on Urban Form. University of Cincinnati, $\mathrm{OH}$.

Greater London Council. 1978. An Introduction to Residential Design. London: GLC.

Jacobs, Jane. 1961. The Death and Life of Great American Cities. New York: Modern Library.

Latour, Bruno. 1993. Never Been Modern. Cambridge: Harvard University Press.

1999. Pandora's Hope: Essays on the Reality of Science Studies Cambridge: Harvard University Press.

Lynch, Kevin. 1960. The Image of the City. Cambridge MA: MIT Press.

Maturana, Humberto. 2001. Cognição, Ciência e Vida Cotidiana. Belo Horizonte: Editora UFMG,.

Rio, João do. 1995 (originally published in 1908). A Alma Encantadora das Ruas. Rio de Janeiro: Secretaria Municipal de Cultura, Departamento Geral de Documentação e Informação Cultural, Divisão de Editoração.

RHEINGANTZ, P.; ALCANTARA, D. 2007. "Cognição experiencial, observação incorporada e sustentabilidade na avaliação pós-ocupação de ambientes urbanos”. In: Ambiente Construído, Porto Alegre, v.7, n.1, p. 35-46.

Rheingantz, Paulo; del Rio, Vicente; DUARTE, Cristiane. 2002. "Cultural Factors: A Needed Category for Post-Occupancy Evaluation." Unpublished paper. [abstract] In Proceedings of EDRA 33. Pennsylvania: EDRA.

Tuan, Yi-Fu. 1974. Topophilia: A Study of Environmental Perceptions, Attitudes, and Values. New York: Columbia University Press.

Tulku, Tartang. 1995. Hidden Mind of Freedom. Berkeley: Nyingma Institute.

Varela, F., Thompson, E., Rosch, E. 1991. The Embodied Mind: Cognitive Science and Human Experience. MIT Press. 


\title{
CONTEMPORARY URBANISM IN BRAZIL: BEYOND BRASILIA
}

\author{
A NEW BOOK EDITED BY \\ VICENTE DEL RIO \& WiLLIAM SIEMBIEDA \\ (UNIVERSITY PRESS OF FLORIDA, 2009)
}

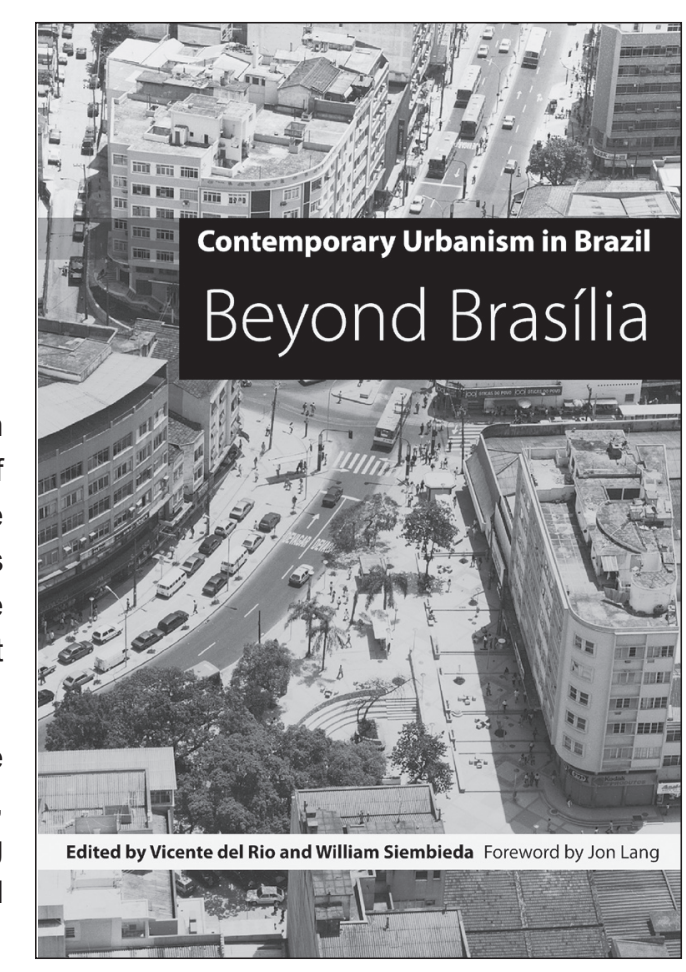

For decades, a succession of military regimes and democratic governments in Brazil sought to shape the future of their society through the manipulation of urban spaces. Cities that reflected the ideals of modernism were built until the post-military period of redemocratization in the mid 1980s. From then, enormous efforts aimed at forging a more responsive urbanism in order to overcome historically determined social and spatial urban inequalities, such as rampant sprawl and the infamous slums known as favelas.

In this collection of 14 essays, architects, urban planners, and scholars assess the legacy of the major trends of contemporary urbanism in Brazil: late-modernism, revitalization, and social inclusion. They examine how cities are regenerating themselves within a democratic political framework that meets market and social demands, and respects place, culture, and history.

"Easily the best book on Brazilian urbanism... (it) opens a door and invites us to enter a magical environment" (Javier de Mesones, founder and honorary president of ISOCARP and of the Spanish Planning Association).

"A landmark study for those interested in contemporary urbanism in developing countries." (Peter Ward, Professor of Public Affairs and Sociology, University Texas at Austin)

"Radically alters our understanding just when Brazil is taking its place on the world global stage. Its focus on urban form, inequality planning, and democracy will interest urban scholar, professionals, and politicians." (Michael Dear, Professor of Geography, University of Southern California)

"An invaluable resource in better understanding this country's exciting urban experience." (Jaime Lerner, threetime Mayor of Curitiba and two-time governor of Parana, Brazil)

"An updated discussion of the city-planning evolution in a country that has exercized leadership in applying state-of-the-art approaches to urban development" (Eduardo Rojas, Principal Urban Development Specialist, Inter-American Development Bank).

“... highly original and outstanding set of detailed case studies... makes a strong case for Brazilian urbanism as a cutting edge laboratory for urban change not only in other Latin American and developing regions of the world, but across all cities." (Lawrence A. Herzog, Professor of City Planning, San Diego State University)

\section{Available from the University Press of Florida, Amazon, and your local bookstore}

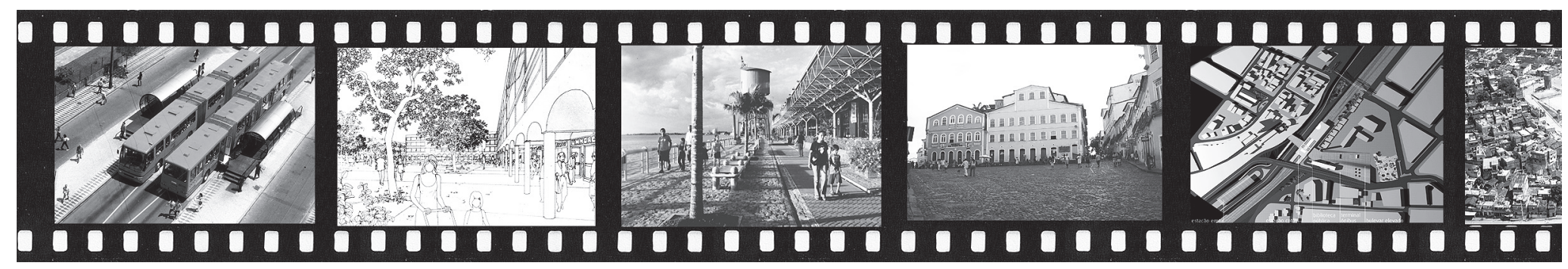

